http://dx.doi.org/10.32929/2446-8355.2021v30n2p136-148

\title{
FERTILIZER CONCENTRATION AND FERTIGATION FREQUENCY: EFFECTS ON ELECTRIC CONDUCTIVITY AND IONS CONCENTRATION IN THE SOIL SOLUTION
}

\author{
Bruno Laecio da Silva Pereira ${ }^{1 *}$, Eugenio Ferreira Coelho ${ }^{2}$, Marcos Sousa Campos ${ }^{1}$, Laina \\ Andrade Queiroz ${ }^{3}$, Carla Caroline Damasceno Bras ${ }^{4}$, Zalmar Santana Gonçalves ${ }^{5}$, Benedito \\ Rios Oliveira ${ }^{6}$
}

\footnotetext{
${ }^{1}$ Doutorado, Engenharia Agrícola, Universidade Federal do Recôncavo da Bahia, Cruz das Almas, Bahia. *Email do autor correspondente: brunolaecio_3@hotmail.com

${ }^{2}$ Pesquisador, Engenharia Agrícola, Embrapa Mandioca e Fruticultura, Cruz das Almas, Bahia.

${ }^{3}$ Engenheira Agronômica, Universidade Federal do Recôncavo da Bahia, Cruz das Almas, Bahia.

${ }^{4}$ Agroecologia, Universidade Federal do Recôncavo da Bahia, Cruz das Almas, Bahia.

${ }^{5}$ Doutorado em Biotecnologia, Universidade Estadual de Feira de Santana, UEFS, Feira de Santana, Bahia.

${ }^{6}$ Mestrado, Engenharia Agrícola, Universidade Federal do Recôncavo da Bahia, Cruz das Almas, Bahia.
}

Recebido: 19/02/2020; Aceito: 06/10/2021

\begin{abstract}
Fertirrigation allows total control of the amount of applied fertilizers to the soil as a function of crop demand. Fertigation relies on monitoring of soil ions to obtain the sustainability of soil chemical conditions. The continuous evaluation of ions in the soil solution also contributes to the estimation of the cycling rate of chemical elements and nutrient leaching in the field. The objective of this work was (i) to evaluate nitrate, potassium, sodium and electrical conductivity in the soil solution submitted to different concentrations of injection solution and fertigation frequency during one cycle of the "Grande Naine" banana in a non-cohesive Yellow Latosol and (ii) to evaluate the effects of concentration and fertigation frequency on yields of banana crop. The experiment was carried out according to a randomized block design with six treatments and four replications in a 3 x 2 factorial scheme with three concentrations of the injection solution (3,10 and $15 \mathrm{~g} \mathrm{~L}-1) \times$ two fertigation frequencies ( 3 and 7 days). The treatments influenced the values of the ion concentration in the soil solution in the soil profile corresponding to the depths of $0-0.30$ e $0.30-0.60 \mathrm{~m}$. The concentration of the injection solution and the interaction frequency $\mathrm{x}$ concentration influenced the electrical conductivity and nitrate concentration of the soil solution. There was no significant effect of the injection solution and fertigation frequency on production variables.
\end{abstract}

Key words: Fertigation. Soil solution. Nitrate and potassium ion.

\section{CONCENTRAÇÃO DE FERTILIZANTES E FREQUÊNCIA DE FERTIRRIGAÇÃO: EFEITOS NA CONDUTIVIDADE ELÉTRICA E CONCENTRAÇÃO DE ÍONS NA SOLUÇÃO DO SOLO}

RESUMO: A fertirrigação possibilita controle da quantidade de fertilizantes que devem ser aplicados ao solo em função da demanda das culturas. Essa aplicação requer o monitoramento 
de íons no solo para garantir a sustentabilidade das condições químicas do mesmo. A avaliação contínua dos íons na solução do solo também contribui para auxiliar nas estimativas das taxas de ciclagem de elementos químicos e na lixiviação de nutrientes no campo. $\mathrm{O}$ objetivo deste trabalho foi (i) avaliar o comportamento dos íons nitrato, potássio, sódio e da condutividade elétrica na solução do solo, quando submetido a diferentes concentrações de solução de fertilizantes e frequências de aplicação ao longo de um ciclo da bananeira "Grande Naine" em um Latossolo Amarelo Distrocoeso e (ii) avaliar os efeitos da concentração e da frequência de aplicação da solução de injeção na produtividade da bananeira. $\mathrm{O}$ experimento foi conduzido com um delineamento experimental em blocos casualizados com seis tratamentos e quatro repetições, em um esquema fatorial $3 \times 2$ sendo três concentrações da solução de injeção (3,10 e $15 \mathrm{~g} / \mathrm{L}$ ) x duas frequências de fertirrigação (3 e 7 dias). Os tratamentos influenciaram o comportamento dos íons no perfil de solo correspondente as profundidades 0-0,30 e 0,30-0,60 m. A condutividade elétrica e a concentração de nitrato da solução do solo foram influenciadas pela concentração da solução de injeção e pela interação frequência e concentração da solução de injeção. Não foi observado efeito da concentração da solução de injeção nem da frequência de fertirrigação nas variáveis de produção.

Palavras-chave: Fertirrigação. Solução do solo. Íons de nitrato e potássio.

\section{INTRODUCTION}

Banana is sensitive to short nutrition and water deficit. It has high transpiration, especially under conditions of high atmospheric demand (FIGUEIREDO et al., 2006). Plant uptakes the following nutrients in a decreasing order: $\mathrm{K}>\mathrm{N}>\mathrm{Ca}>\mathrm{Mg}>\mathrm{S}>\mathrm{P}>\mathrm{Cl}>\mathrm{Mn}>\mathrm{Fe}>\mathrm{Zn}>\mathrm{B}>\mathrm{Cu}$. However, nutrient uptake differs among cultivars with respect to the quantities, mainly due to genetic characteristics, nutrient contents in the soil and the management adopted Borges and Silva Junior (2001).

Thus, fertigation enables the controlled application of nutrients adjusted to the phenological stages (COELHO et al., 2018) and, despite favoring the achievement of high yields in irrigated crops, if poorly managed, it can considerably increase the concentration of salts in the soil that, when exceeding plant tolerance limits, negatively affects crop growth and productivity (SILVA et al., 2013).

The use of fertigation has progressively increased, especially in trickle irrigation systems. There is still short information on its correct management and on the possible impacts from the intensive use of this technique on the soil. The knowledge of dynamics of ions in the soil solution, particularly nitrate and potassium, is necessary because of the risk of leaching and contamination of groundwater (MARTINS et al., 2011; TEIXEIRA et al., 2011).

The technique of applying fertilizers via irrigation water is called fertigation and has great applicability in agriculture, especially in the production of fruits and vegetables (PEREIRA et al., 2016), but it is not limited to these crops. In this, the use of soluble formulations can be highlighted, which has advantages such as concentration and frequency that can be easily changed according to the requirements of cultivation, and its use is systematized according to the irrigation infrastructure, with the use of agricultural products 
such as urea, potassium chloride and simple superphosphate are a simple and easily acquired alternative to perform this activity (HOSHINO et al., 2016)

Ion concentration of soil solution under fertigation conditions has been shortly studying. The knowledge of ions like nitrate in different soil depths is necessary for evaluation the impacts of fertigation, mainly with use of nitrate-based fertilizers. Fertigation also needs continuous evaluation since salty water moves in the soil profile as mass flux and some criteria for fertilizer application is necessary to prevent negative impacts mainly in the chemical attributes of the soil. Soil chemical attributes that need concern are the soil electric conductivity (CE) and nitrate. Values of electric conductivity of the soil solution (CEw) where roots uptake water and nutrients has to be considered for soil salinity evaluation purposes. Leaching of nitrate in excess may results in groundwater contamination.

There are still doubts concerning which fertilizer concentration to use in the injection solution. High concentrations at the emitter outlet can cause clogging, especially in periods of interruption of irrigation, which favor the deposition of salts in the emitters. High concentrations of fertilizer may also cause increase in the soil solution electrical conductivity in short periods of time (COELHO et al., 2014).

Franco et al. (2017) point out that further studies are needed for the dissemination of this method in the management of fertigation, with emphasis mainly on the nutritional status of plants. If excess nitrate in the soil solution persists between crops, it can leach with rainwater. The result is that, with increasing frequency, concentrations of this nutrient in plants are reached in the saturated zone of the soil, which can affect human health and environmental quality (ARAUZO, 2003; CARVALHO; ZABOT, 2012).

This study aimed to: (i) evaluate nitrate, potassium, sodium ions and electrical conductivity in the soil solution under different fertilizer concentrations in irrigation water and fertigation frequencies along a cycle of banana cv. Grand Naine; (ii) evaluate the influence of the fertilizer concentration in irrigation water on the yield of this banana cultivar.

\section{MATERIAL AND METHODS}

The experiment was carried out in the experimental area of Embrapa Cassava \& Tropical Fruits, in Cruz das Almas, Bahia, Brazil, located at 12 $40^{\prime} 19^{\prime \prime} \mathrm{S}, 39^{\circ} 06^{\prime} 23^{\prime \prime} \mathrm{W}$, at altitude of $225 \mathrm{~m}$. The local climate has classification as hot and humid tropical, Aw and Am, according to the Köppen-Geiger classification. The site has mean annual records, from the last five years (2012-2017), of maximum, minimum and mean temperatures, relative air humidity and cumulative rainfall of approximately $29.02{ }^{\circ} \mathrm{C}, 20.8{ }^{\circ} \mathrm{C}, 23.9^{\circ} \mathrm{C}, 82.8 \%$ and $1069 \mathrm{~mm}$ year $^{-1}$, respectively.

The experiment was carried out from September 2015 (495 days after planting - DAP) to September 2016 (860 DAP). The rains are represented in Figure 1. The experimental area was prepared before transplanting the "Grand Naine" banana seedlings, which occurred on $10 / 15 / 2014$, in a spacing of $2.0 \times 2.5 \mathrm{~m}$. The planting holes were opened with the aid of an agricultural implement, adjusted to approximately $0.5 \times 0.5 \mathrm{~m}$ and $0.30 \mathrm{~m}$ in depth. The foundation fertilization was based on the analysis of the physical (Table 1) and chemical 
(Table 2) attributes of the soil (TEXIREIRA et al., 2017), with fertilizer recommendations for the banana tree, followed by Borges and Souza (2009) for implantation in Cohesive Dystrophic Yellow Latosol (SANTOS et al., 2013), were manually performed per pit, with distribution of 12 liters of tanned cattle manure, $70 \mathrm{~g}$ of a mixture of micronutrients FTE BR 12 and $150 \mathrm{~g}$ of simple superphosphate. The indexed micropropagated seedlings came from Campo's biofactory, installed on the premises of Embrapa Cassava e Fruticultura. Cultural treatments: the control of invasive plants was carried out manually, through weeding, thinning and defoliation according to the recommendations of Alves et al. (2004). Being fertigated by a micro sprinkler system with $60 \mathrm{~L} \mathrm{~h}^{-1}$ flow emitters. The irrigations were based on the simplified water balance of the soil Coelho et al. (2012), using soil moisture data collected by time domain reflectometry (TDR).

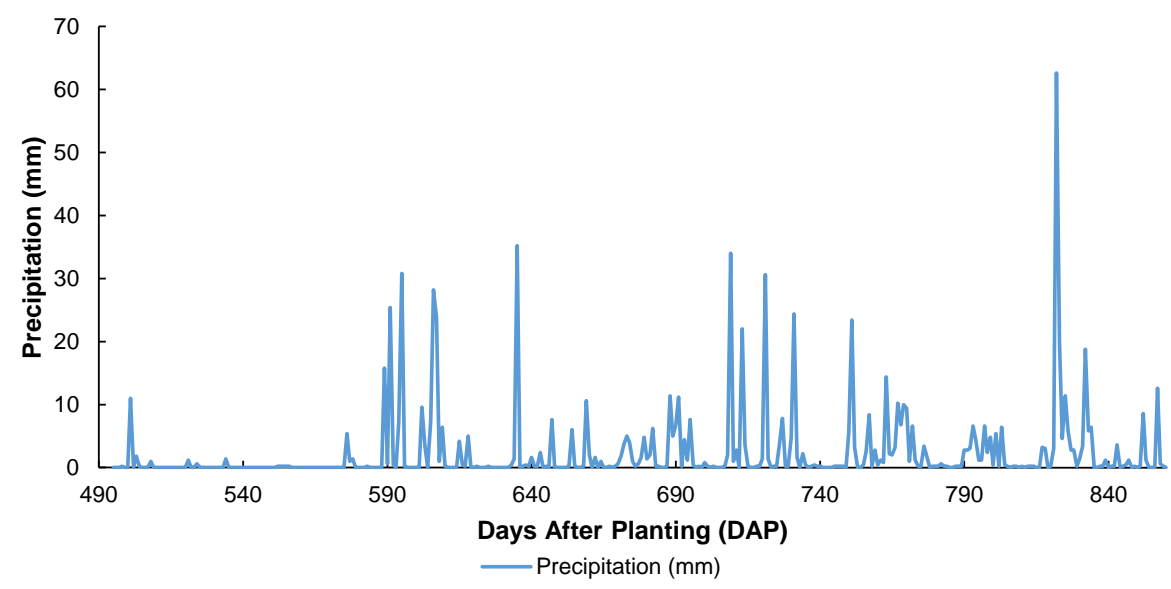

Figure 1. Distribution of precipitation ( $\mathrm{mm}$ ) during banana cycle.

Source: Own authorship.

Table 1. Porosity, density, granulometry and textural classification of the soil, evaluated at depth 0-0.30 m, before the installation of the experiment. Cruz das Almas, BA. 2014.

\begin{tabular}{|c|c|c|c|c|c|c|c|c|}
\hline \multirow{2}{*}{$\begin{array}{c}{ }^{1} \text { Depth. } \\
(\mathrm{m})\end{array}$} & \multicolumn{3}{|c|}{ Porosity (\%) } & \multirow{2}{*}{$\begin{array}{c}{ }^{2} \mathrm{Ds} \\
\left(\mathrm{g} \mathrm{cm}^{-3}\right)\end{array}$} & \multicolumn{3}{|c|}{ Granulometry $\left(\mathrm{g} \mathrm{kg}^{-1}\right)$} & \multirow{2}{*}{$\begin{array}{c}\text { Textural } \\
\text { classification }\end{array}$} \\
\hline & Total & Macro & Micro & & Total sand & Silt & Clay & \\
\hline $0.00-0.30$ & 34.00 & 6.54 & 27.46 & 1.59 & 630 & 128 & 242 & sandy clay franc \\
\hline $0.30-0.60$ & 36.65 & 6.90 & 29.45 & 1.70 & 593 & 114 & 293 & clay franc \\
\hline
\end{tabular}

${ }^{1}$ Depth. ${ }^{2}$ Ds: Soil density.

Source: Own authorship.

Table 2. Analysis of the chemical attributes of the soil before the installation of the experiment at a depth of 0-0.30m. Cruz das Almas, BA. 2015.

\begin{tabular}{|c|c|c|c|c|c|c|c|c|c|c|c|c|}
\hline \multirow{2}{*}{$\begin{array}{c}{ }^{1} \text { Depth. } \\
\text { (m) }\end{array}$} & \multirow{2}{*}{$\begin{array}{c}\mathrm{pH} \\
\left(\mathrm{H}_{2} \mathrm{O}\right)\end{array}$} & \multirow{2}{*}{$\begin{array}{c}{ }^{2} \mathrm{P} \\
\left(\mathrm{mg} \mathrm{dm}^{-3}\right)\end{array}$} & ${ }^{2} \mathrm{~K}$ & ${ }^{3} \mathrm{Ca}$ & ${ }^{3} \mathrm{Mg}$ & ${ }^{3} \mathrm{Al}$ & ${ }^{2} \mathrm{Na}$ & $\mathrm{H}+\mathrm{Al}$ & SB & CTC & \multirow{2}{*}{$\begin{array}{l}\mathrm{V} \\
\%\end{array}$} & \multirow{2}{*}{$\begin{array}{l}{ }^{4} \mathrm{MO} \\
\mathrm{g} \mathrm{kg}^{-1}\end{array}$} \\
\hline & & & \multicolumn{8}{|c|}{$\left(\mathrm{cmolc} \mathrm{dm}^{-3}\right)$} & & \\
\hline $0.00-0.30$ & 5.41 & 8 & 47 & 1.90 & 0.80 & 0.10 & 0.04 & 2.50 & 2.60 & 5.36 & 53.35 & 11.30 \\
\hline $0.30-0.60$ & 5.26 & 5 & 36 & 1.20 & 0.80 & 0.10 & 0.04 & 2.70 & 2.13 & 4.83 & 44.09 & 9.60 \\
\hline
\end{tabular}

${ }^{1}$ Depth; SB: sum of exchangeable bases; CTC: cation exchange capacity; V: base saturation and MO: organic matter. ${ }^{2}$ Mehlich-1 extraction; ${ }^{3}$ Extraction with $1 \mathrm{M} \mathrm{KCl} ;{ }^{4}$ Modified Walkley \& Black method.

Source: Own authorship.

The experimental design was as randomized block with six treatments and four replicates, with ten plants per plot, four of which were used for evaluation. The experiment 
followed a 3 x 2 factorial arrangement, corresponding to three injection solution concentrations and two fertigation frequencies. Nitrate and potassium concentrations in the injection solution were 3,10 and $15 \mathrm{~g} \mathrm{~L}^{-1}$. These concentrations were defined on previous experiments (COELHO et al., 2014). Fertigation frequencies were 3 and 7 days, values recommended for the banana crop. Treatments were $\mathrm{T} 1=3 \mathrm{~g} \mathrm{~L}^{-1}$ and 7-day frequency; $\mathrm{T} 2=$ $10 \mathrm{~g} \mathrm{~L}^{-1}$ and 7-day frequency; $\mathrm{T} 3=15 \mathrm{~g} \mathrm{~L}^{-1}$ and 7-day frequency; $\mathrm{T} 4=3 \mathrm{~g} \mathrm{~L}^{-1}$ and 3-day frequency; $\mathrm{T} 5=10 \mathrm{~g} \mathrm{~L}^{-1}$ and 3-day frequency; $\mathrm{T} 6=15 \mathrm{~g} \mathrm{~L}^{-1}$ and 3-day frequency. Nitrogen (N) and Potassium $\left(\mathrm{K}_{2} \mathrm{O}\right)$ were according to recommendation of Borges et al. (2006) by potassium nitrate and urea. Soil solution samples were collected monthly in all treatments at a distance of $0.20 \mathrm{~m}$ from the pseudostem at 0.30 and $0.70 \mathrm{~m}$ depths. Soil physical and chemical analyses were according to the methodology of EMBRAPA (2011). Soil solution was analyzed in laboratory; nitrate was determined using a quick test kit, whereas potassium and sodium were determined by photometry (EMBRAPA, 2011). In addition, the following biometric variables were also evaluated: number of leaves, third leaf length and width, pseudostem diameter, number of fingers, number of hands, bunch weight and yield. The data were submitted to variance analysis in order to evaluate the effects of factors (treatments) on dependent variables and to compare means of these variables by using Scott-Knott test at 0.05 probability level.

\section{RESULTS AND DISCUSSION}

\section{Ion concentration and soil solution electric conductivity}

Electric conductivity $\left(\mathrm{EC}, \mathrm{dS} \mathrm{m}{ }^{-1}\right)$, nitrate $\left(\mathrm{NO}_{3}{ }^{-}, \mathrm{mg} \mathrm{L}^{-1}\right)$, potassium $\left(\mathrm{K}, \mathrm{mg} \mathrm{L}^{-1}\right)$, sodium $\left(\mathrm{Na}, \mathrm{mg} \mathrm{L}^{-1}\right)$ in the soil solution analyzed in the $0-0.30 \mathrm{~m}$ depth were not influenced by either fertigation frequency or concentration of injection solution (Table 2). These results should not expected because lower irrigation frequency associated with higher concentration of the injection solution is supposed to favor a higher concentration of these ions in the root zone.

Table 2. Means of soil solution electric conductivity $(\mathrm{CEw})$, nitrate $\left(\mathrm{NO}_{3}{ }^{-}\right)$, potassium $(\mathrm{K})$ and sodium $(\mathrm{Na})$ in the $0-0.30 \mathrm{~m}$ layer because of two fertigation frequencies and three concentrations of irrigation water.

\begin{tabular}{cccccc}
\hline $\begin{array}{c}\text { Frequency } \\
\text { (day) }\end{array}$ & $\begin{array}{c}\text { Concentration } \\
\left(\mathrm{g} \mathrm{L}^{-1}\right)\end{array}$ & $\mathrm{CE}\left(\mathrm{dSm}^{-1}\right)$ & $\mathrm{NO}_{3}-\left(\mathrm{mg} \mathrm{L}^{-1}\right)$ & $\mathrm{K}\left(\mathrm{mg} \mathrm{L}^{-1}\right)$ & $\mathrm{Na}\left(\mathrm{mg} \mathrm{L}^{-1}\right)$ \\
\hline \multirow{2}{*}{3} & 3 & 1.60 & 81.08 & 81.66 & 131.50 \\
& 10 & 1.99 & 68.66 & 69.66 & 119.97 \\
& 15 & 1.24 & 69.83 & 86.33 & 113.85 \\
\hline \multirow{2}{*}{7} & 3 & 1.03 & 53.25 & 77.91 & 141.08 \\
& 10 & 1.39 & 66.50 & 107.58 & 140.90 \\
& 15 & 0.93 & 70.83 & 68.00 & 138.43 \\
\hline
\end{tabular}

Source: Own authorship.

The interaction between frequency and concentration showed effect of concentrations on electrical conductivity, on nitrate, on potassium and sodium only for the 7-day frequency, 
at $0.30-0.70 \mathrm{~m}$ depth. At this fertigation frequency, except for nitrate, the means of chemical attributes did not differ between fertilizer solution concentrations of 10 and $15 \mathrm{~g} \mathrm{~L}^{-1}$. Means of nitrate under fertilizer concentrations differed from one another. The higher means of ion concentrations occurred for $10 \mathrm{~g} \mathrm{~L}^{-1}$, whereas the smaller ones occurred for $3 \mathrm{~g} \mathrm{~L}^{-1}$ (Table 3 ). These results are consistent because the amount of fertilizers applied at 7-day frequency is twice the one applied every 3 days. Moreover, 7-day frequency coupled with $15 \mathrm{~g} \mathrm{~L}^{-1}$ concentration, led to larger leaching of these ions, mainly nitrate, whose concentration means in the soil solution differed according to water fertilizer concentration. Soil solution concentration was larger for water fertilizer concentration. of $15 \mathrm{~g} \mathrm{~L}^{-1}$ and smaller for $3 \mathrm{~g} \mathrm{~L}^{-1}$. Nitrate concentrations in soil solution for the 3-day frequency were smaller than the ones reported by Coelho et al. (2014) and Cruz et al. (2017), who observed nitrate concentrations of 78.0 and $225.0 \mathrm{mg} \mathrm{L}^{-1}$, when applying different concentrations of ammonium nitrate to the soil. Part of the results was within the ranges found by Cometti et al. (2008), i.e., from 21.8 to $174 \mathrm{mg} \mathrm{L}^{-1}$.

Table 3. Means of soil solution electric conductivity $(\mathrm{CEw})$, nitrate $\left(\mathrm{NO}_{3}{ }^{-}\right)$, potassium $(\mathrm{K})$ and sodium $(\mathrm{Na})$ in $0.30-0.70 \mathrm{~m}$ layer because of two fertigation frequencies and three concentrations of irrigation water.

\begin{tabular}{cccccc}
\hline $\begin{array}{c}\text { Frequêncy } \\
(\text { dias })\end{array}$ & $\begin{array}{c}\text { Concentration } \\
\left(\mathrm{g} \mathrm{L}^{-1}\right)\end{array}$ & $\mathrm{CE}\left(\mathrm{dS} \mathrm{m}^{-1}\right)$ & $\mathrm{NO}_{3}{ }^{-}\left(\mathrm{mg} \mathrm{L}^{-1}\right)$ & $\mathrm{K}\left(\mathrm{mg} \mathrm{L}^{-1}\right)$ & $\mathrm{Na}\left(\mathrm{mg} \mathrm{L}^{-1}\right)$ \\
\hline \multirow{2}{*}{3} & 3 & 0.53 & 27.75 & 57.68 & 126.70 \\
& 10 & 0.76 & 36.66 & 83.08 & 145.46 \\
& 15 & 0.66 & 30.91 & 61.78 & 140.86 \\
\hline \multirow{2}{*}{7} & 3 & $0.47 \mathrm{~b}$ & $17.91 \mathrm{c}$ & $43.06 \mathrm{~b}$ & $101.18 \mathrm{~b}$ \\
& 10 & $0.84 \mathrm{a}$ & $73.08 \mathrm{a}$ & $98.92 \mathrm{a}$ & $148.19 \mathrm{a}$ \\
& 15 & $0.61 \mathrm{ab}$ & $40.66 \mathrm{~b}$ & $73.89 \mathrm{ab}$ & $137.41 \mathrm{ab}$ \\
\hline
\end{tabular}

Source: Own authorship.

Mean values of $\mathrm{EC}\left(\mathrm{dS} \mathrm{m}{ }^{-1}\right)$ and concentrations of $\mathrm{NO}_{3}{ }^{-}, \mathrm{K}$ and $\mathrm{Na}\left(\mathrm{mg} \mathrm{L}^{-1}\right)$ in the soil solution at layers 0-0.30 $\mathrm{m}$ and 0.30-0.70 $\mathrm{m}$ depths are in Table 3. Soil depth influenced EC $\left(\mathrm{dS} \mathrm{m}{ }^{-1}\right)$ and $\mathrm{NO}_{3}{ }^{-}$. The means of $\mathrm{EC}$ and $\mathrm{NO}_{3}{ }^{-}$in soil solution at $0-0.30 \mathrm{~m}$ were larger than at $0.30-0.70 \mathrm{~m}$. The larger nitrate concentration in the shallower layer is due to the higher content of organic matter from the banana phytomass that returns to the soil surface. This phytomass contributes to raising the negative charges of colloids, at $0-0.30 \mathrm{~m}$ with reduction of nitrate adsorption compared with the adsorption in deeper layers $(0.30-0.70 \mathrm{~m})$, in which there is a reduction of organic matter Oliveira et al. (2001). Despite the non-difference between the mean concentrations of potassium in the soil solution at both depths, its higher absolute concentration in the $0-0.30 \mathrm{~m}$ depth was mainly due to the larger nutrient cycling in shallower layers (JOBBAGY; JACKSON, 2001).

The results obtained (Table 4) were similar to those found by Franco (2009), who evaluated application of potassium nitrate in the soil and observed that the higher means of EC $\left(\mathrm{dSm}^{-1}\right)$ and concentrations of ions in the soil solution occurred in the upper layers, for both clayey and sandy soils. Potassium is reported as the faster released nutrient Espíndola et al. (2006); Boer et al. (2007), because it is not associated with any structural component in the 
plant tissue, when in the ionic form. Potassium concentration favored the sodium concentration in $0-0.30 \mathrm{~m}$ layer, but lower concentration was found in $0.30-0.70 \mathrm{~m}$, which may be related to the competition with potassium ions from the absorption sites.

Table 4. Comparison of means of soil solution electric conductivity (CEw), nitrate $\left(\mathrm{NO}_{3}{ }^{-}\right)$, potassium $(\mathrm{K})$ and sodium $(\mathrm{Na})$ concentrations in soil solution by Tukey test at $5 \%$ probability level at depths of $0-0.30$ e $0.30 .0 .70 \mathrm{~m}$.

\begin{tabular}{ccccc}
\hline Depth $(\mathrm{m})$ & $\mathrm{CE}\left(\mathrm{dS} \mathrm{m}^{-1}\right)$ & $\mathrm{NO}_{3}^{-}\left(\mathrm{mg} \mathrm{L}^{-1}\right)$ & $\mathrm{K}\left(\mathrm{mg} \mathrm{L}^{-1}\right)$ & $\mathrm{Na}\left(\mathrm{mg} \mathrm{L}^{-1}\right)$ \\
\hline $0-0.30$ & $1.36 \mathrm{a}$ & $68.36 \mathrm{a}$ & $81.86 \mathrm{a}$ & $130.95 \mathrm{a}$ \\
$0.30-0.70$ & $0.65 \mathrm{~b}$ & $37.83 \mathrm{~b}$ & $69.74 \mathrm{a}$ & $133.30 \mathrm{a}$ \\
\hline
\end{tabular}

Source: Own authorship.

The increase of potassium and sodium concentrations in the soil solution along time during the second crop cycle (Figure $2 \mathrm{a}, \mathrm{b}, \mathrm{c}$ and d) demonstrates that there is not a defined behavior of these ions concentrations in the soil solution under different concentrations of fertilizer in irrigation water.
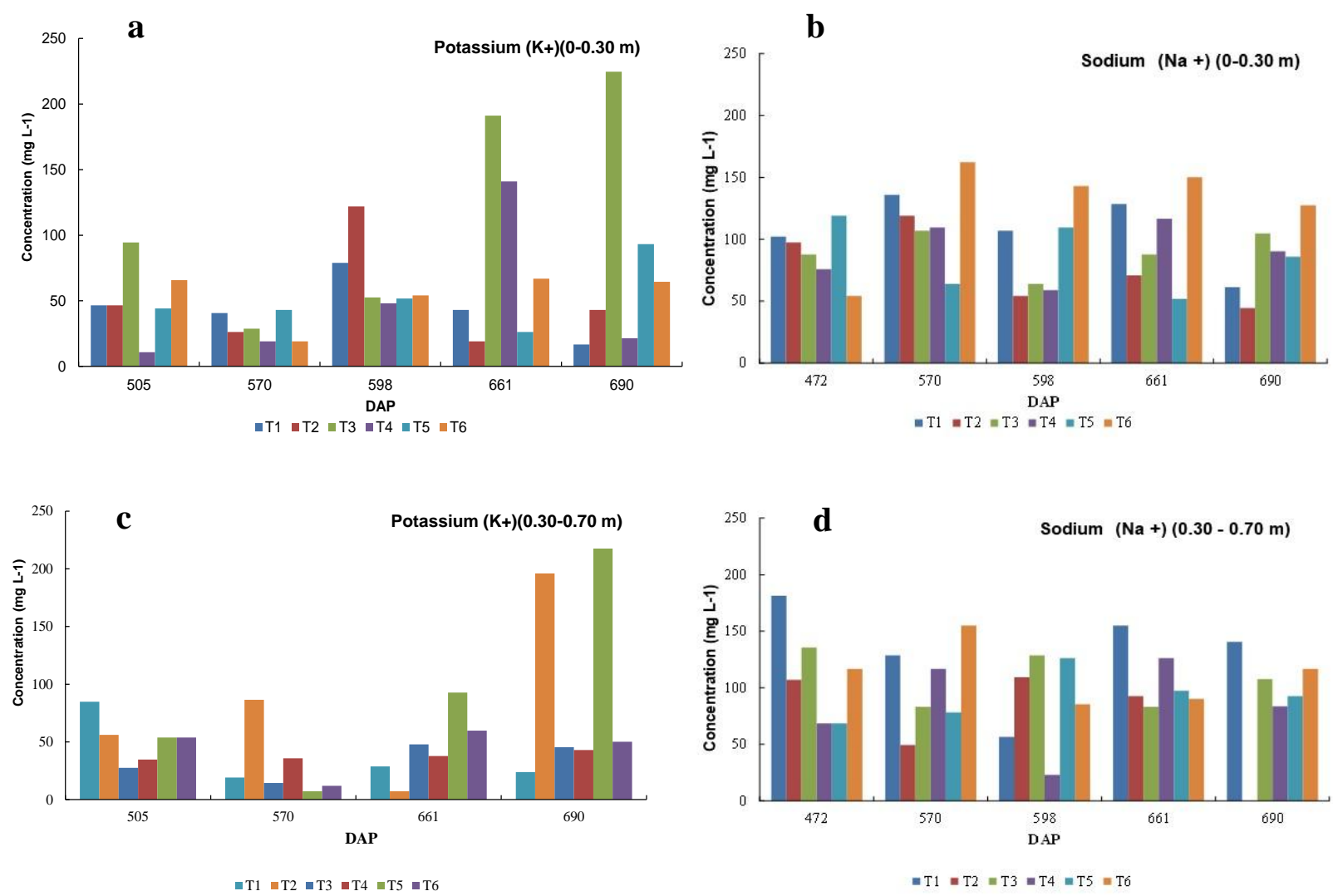

Figure 2. Concentration of $\mathrm{K}^{+} \mathrm{e} \mathrm{Na}^{+}\left(\mathrm{mg} \mathrm{L}^{-1}\right)$, in the layer of $0-0.30 \mathrm{~m}$ during the period of 505 to 690 DAP (a, c) and during the period of 472 to 690 DAP $(b, d)$ for treatments. Source: Own authorship.

The mean values of nitrate concentrations at $0.30 \mathrm{~m}$ and $0.70 \mathrm{~m}$ depths (Figure $3 \mathrm{a}$ and b) were between 88 and $89 \mathrm{mg} \mathrm{L}^{-1}$ (T1); between 124 and $146 \mathrm{mg} \mathrm{L}^{-1}$ (T2); between 101 and $155 \mathrm{mg} \mathrm{L}^{-1}$ (T3); between 141 and $348 \mathrm{mg} \mathrm{L}^{-1}$ (T4); between 140 and $134 \mathrm{mg} \mathrm{L}^{-1}$ (T5) and between 98 and $177 \mathrm{mg} \mathrm{L}^{-1}$ (T6) along the cycle. The mean nitrate concentrations observed in $\mathrm{T} 1$ are similar to those obtained by Oliveira et al. (2001), in a study carried in Yellow Latosol 
cultivated with sugarcane, where the $\mathrm{NO}_{3}{ }^{-}$concentrations in the soil solution varied from 48.1 to $124.5 \mathrm{mg} \mathrm{L}^{-1}$. Andrade Neto \& Coelho (2008) obtained different results; they evaluated the effect of urea and calcium nitrate in the soil solution and found an increment in nitrate concentration in the soil solution at the $0.40 \mathrm{~m}$ depth compared with the $0.20 \mathrm{~m}$ depth. Cruz et al. (2017) observed increase of up to $500 \%$ in nitrate concentration in the soil solution at 1.0 $m$ depth compared with more superficial soil layers. Matos and Matos (2017) found increment in nitrate concentrations in layers below $0.20-0.30 \mathrm{~m}$, in soil profile when using wastewater treatment.
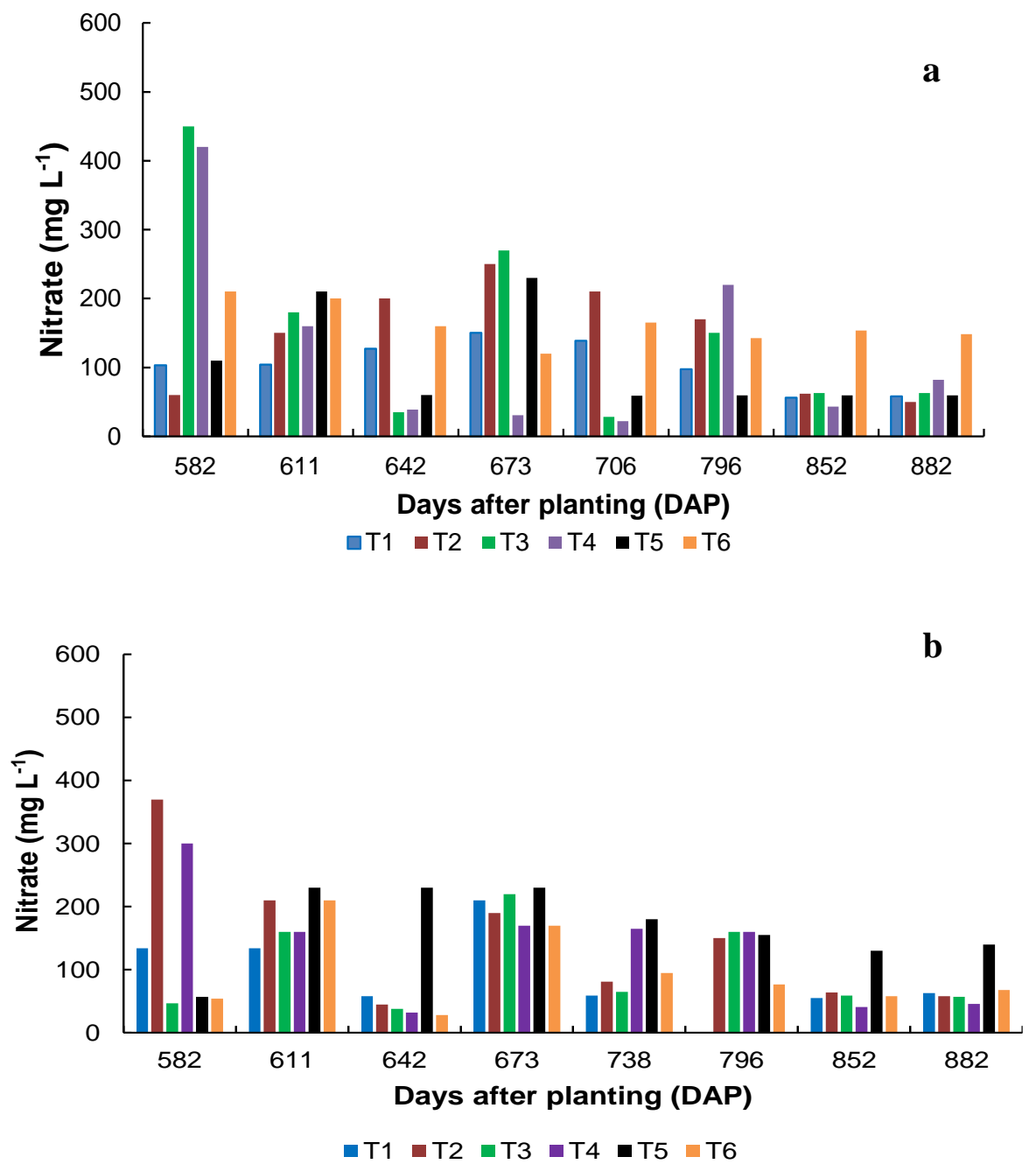

Figure 3. Nitrate concentration $\left(\mathrm{NO}_{3}{ }^{-}\right)$, at depths of $0-0.30 \mathrm{~m}$ (a) $0.30-0.70 \mathrm{~m}$ (b) from 582 to 882 days after planting (DAP).

Source: Own authorship.

The ECw did not show a specific behavior that could be related to the time (Figure 4a, $4 \mathrm{~b}$ ), as the other variables. The behavior of the individual values of each treatment may be linked to the rainfall regime, i.e., with larger dilution, with decrease of the concentrations during rainfall season and the opposite during drought season. All treatments showed larger nitrate concentrations until 642 DAP which decreased at 673 DAP keeping a slight variation over time. However, a relevant increase occurred in all treatments after 852 DAP at the end of rainfall season. 
The results demonstrate that either concentration of irrigation water or frequency of fertigation did not influence soil solution electrical conductivity. The ECW values obtained in the profile were smaller than the ones considered as a limiting condition for banana development, i.e., $1.1 \mathrm{dS} \mathrm{m}^{-1}$ according to Oliveira (1999) (Figure $4 \mathrm{a}$ and b). According to Silva et al. (2002), banana has good development in soil with electric conductivity up to 1.0 $\mathrm{dS} \mathrm{m} \mathrm{m}^{-1}$ and its production is compromised at higher EC levels.
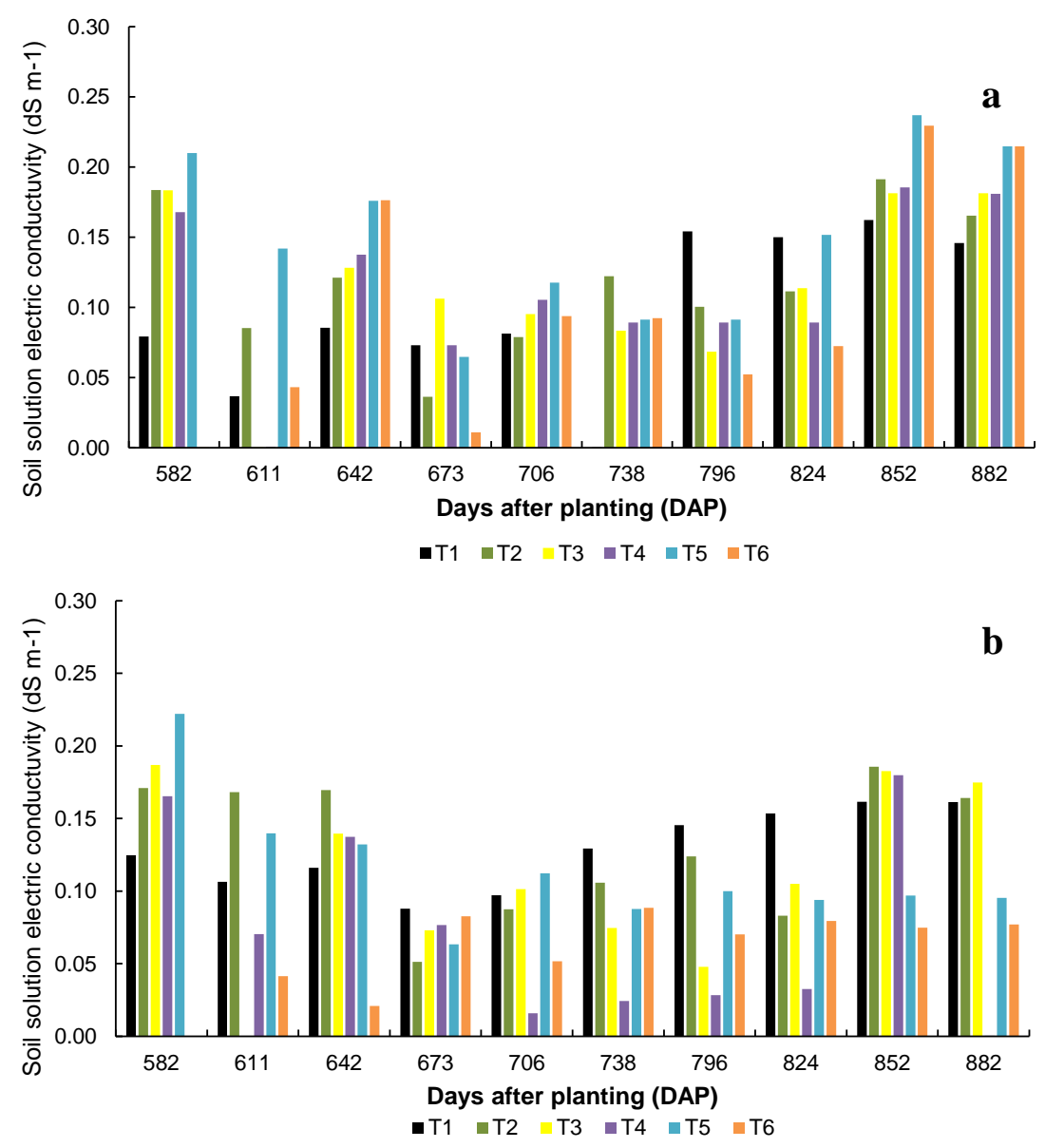

Figure 4. Soil solution electric conductivity in (a) 0-0.30 m layer and (b) 0.30-0.70 m layer during the period of 582 to 910 days after planting (DAP).

Source: Own authorship.

\section{Crop Growth and Yield}

The analysis of variance showed no significant effect of treatments on the number of leaves, third leaf length and pseudostem diameter (Table 5). Variations in injection solution concentration and fertigation frequency did not lead to variations in growth variables.

The analysis of variance demonstrated no effect of injection solution concentration, application frequency or interaction between these sources of variation on the banana production variables (Table 6), and the mean yields ranged from $46.33 \mathrm{t} \mathrm{ha}^{-1}$ to $47.47 \mathrm{t} \mathrm{ha}^{-1}$. These results can be justified by the same amount of fertilizer applied along the cycle for all treatments, although the concentrations of irrigation water might have influenced nutrient uptake. 
Table 5. Mean growth variables of Grande Naine for different concentrations of fertilizer in irrigation water and frequencies of fertigation in the second production cycle.

\begin{tabular}{cccc}
\hline TREATMENTS & NLEAVES & TLL $(\mathrm{m})$ & PD $(\mathrm{cm})$ \\
\hline 1 & 5.75 & 2.17 & 30.83 \\
2 & 5.74 & 2.22 & 29.38 \\
3 & 6.11 & 2.28 & 28.26 \\
4 & 5.75 & 2.22 & 27.78 \\
5 & 5.97 & 2.2 & 30.91 \\
6 & 6.16 & 2.06 & 30.66 \\
\hline CV $(\%)$ & 11.70 & 4.09 & 8.17
\end{tabular}

Note: NLEAVES $=$ number of leaves; TLL $=$ third leaf length; PD = pseudostem diameter.

Source: Own authorship.

Table 6. Mean production variables of Grand Naine for different concentrations of fertilizer in irrigation water and frequencies of fertigation in the second production cycle.

\begin{tabular}{ccccc}
\hline TREATMENTS & NFINGERS & NHANDS & BW $(\mathrm{kg})$ & BW (t ha-1) \\
\hline 1 & 159.1 & 10.01 & 24.63 & 46.33 \\
2 & 157.46 & 9.8 & 25.64 & 45.55 \\
3 & 161.87 & 9.81 & 25.74 & 47.15 \\
4 & 171.95 & 10.41 & 25.89 & 47.47 \\
5 & 178.71 & 10.59 & 25.89 & 46.33 \\
6 & 165.93 & 10.2 & 25.89 & 46.58 \\
\hline CV $(\%)$ & 7.38 & 4.2 & 9.89 & 9.6
\end{tabular}

Nota: NFINGERS $=$ number of fingers/bunch, NHANDS = number of hands/bunch, BW = bunch weight (t ha-1) and bunch weight (t ha-1).

Source: Own authorship.

\section{CONCLUSION}

The interaction between different concentrations and application frequencies of injection solution had no effect on soil solution electrical conductivity.

Higher potassium and nitrate concentrations in soil solution occurred in shallower layer (0-0.30 m), decreasing in subsurface.

Injection solution concentrations in the range of 5 to $15 \mathrm{~g} \mathrm{~L}^{-1}$ and fertigation frequencies of 3 and 7 days did not influence either growth or yield of the banana cv. Grand Naine.

\section{REFERENCES}

ALVES, E. J.; LIMA, M. B.; CARVALHO, J. E. B.; BORGES, A. L. Tratos culturais e colheita. In: BORGES, A.L. E SOUZA, L. S. O cultivo da bananeira. Cruz das Almas: Embrapa Mandioca e Fruticultura, 2004. p.32-44.

ANDRADE NETO, T. M.; COELHO, E. F. Monitoring of ions in soil solution and in the saturation extract under the application of different concentrations of fertilizing salts in 
irrigation water in banana of the earth. 2008. $89 \mathrm{f}$. Master's Dissertation (Graduate Course in Agrarian Sciences) - Federal University of Recôncavo da Bahia, Cruz das Almas, 2008.

ARAUZO, M.; DÍEZ, J. A.; HERNÁIZ, P. Estimación de balances hídricos y lixiviación de nitratos en sistemas agrícolas. In: ALVAREZ-BENEDÍ, J.; MARINERO, P. Estudios de La Zona No Saturada del Suelo. v. 6, Valladolid: Instituto Tecnológico Agrário, 2003. cap. 6, p. 39-44.

BOER, C. A.; ASSIS, R. L.; SILVA, G. P.; BRAZ, A. J. B. P.; BARROSO, A. L.; CARGNELUTTI FILHO, A.; PIRES, F. R. Nutrient cycling by cover crops in the dry season in a closed soil. Pesquisa Agropecuária Brasileira, Brasília, v. 42, n. 9, p.1269-1276, 2007.

BORGES, A. L.; SILVA JÚNIOR, J. F., Liming and fertilization. In: ALVES, E. J. Ground banana cultivation. Cruz das Almas: EMBRAPA Cassava and Fruticultura, 2001, p. 35-40.

BORGES, A. L.; COELHO, E. F.; COSTA, E. L.; SILVA, J. T. A. Fertigation of banana leaves. Cross of the 115 Souls, BA: Embrapa Mandioca and Fruticultura, 2006. 84 p. (Circular Técnica, 84).

COELHO, E. F. Irrigation of the banana tree. Brasília, DF: Embrapa, 2012. 280 p.

COELHO, E. F.; COSTA, F. S; SILVA, A. C. P.; CARVALHO, G. C., Nitrate concentration in the soil profile fertigated with different concentrations of nitrogen sources. Revista Brasileira de Engenharia Agrícola e Ambiental, Campina Grande, v. 18, n. 3, p.263-269, 2014.

COELHO, E. F.; ANDRADE NETO, T. M.; BARROS, D. L., Concentration of injetion solution and its effects on soil and on yield of fertirrigated banana cv. Terra Maranhão. Engenharia Agrícola, Jaboticabal, v. 34, n. 6, p.1104-1113, 2014.

COELHO, V. P. M., ROSA, K. M., PAIVA, P. E. B., MOREIRA, E. F. A.; CARVALHO, M. Fertigation and growth regulator on coffee seedling production in tubes. Pesquisa Agropecuária Tropical, Goiânia, GO, v. 48, n. 4, p.350-357, 2018.

COMETTI, N. N.; MATIAS, G. C. S.; ZONTA, E.; MARY, W.; FERNANDES, M. S., Effect of nutrient solution concentration on lettuce growth in hydroponic culture-NFT system. Horticultura Brasileira, Brasília, v. 26, n. 2, p.262-267, 2008.

CRUZ, C. J. D.; PARRON, L. M.; ROCHA, A. L. A. Availability and mobility of ions in soil solution under coffee crop. In: NATIONAL SYMPOSIUM CLOSED, 12, 2008, Brasília. Anais [...], Brasília: Embrapa Cerrado 2008. p. 1-6.

ESPÍNDOLA, J. A. A.; WAR, J. G. M.; ALMEIDA D. L.; TEIXEIRA, M. G.; URQUIAGA, S. Decomposition and release of accumulated nutrients in perennial herbaceous legumes intercropped with banana. Revista Brasileira de Ciência do Solo, Viçosa, v. 30, n. 2, p.321328, 2006.

BORGES, A. L.; SOUZA, L. S. (Ed.). O cultivo da bananeira. Cruz das Almas: Embrapa, 2009. $279 \mathrm{p}$.

BRAZILIAN COMPANY OF AGRICULTURAL RESEARCH - EMBRAPA. Manual of soil analysis methods. 2. ed. Rio de Janeiro: National Soil Research Center, 2011. 212 p. 
FRANCO E. M. Monitoring of the dynamics of water and solutes in a soil profile, under a drip fertigation system, using capacitance probe and solution extractors. 2009. $85 \mathrm{f}$. Dissertation (Master in Irrigation and Drainage) - Luiz de Queiroz College of Agriculture, University of São Paulo, Piracicaba, 2009.

FRANCO, E. M.; MIRANDA, J. H.; DUARTE, S. N.; SILVA DIAS, N.; BISSI JUNIOR, C. J., FERNANDES, C. S. Percolação de solutos em solo fertirrigado por gotejamento, utilizando extratores de solução. Revista Brasileira de Agricultura Irrigada, Fortaleza, v. 11, n. 1, p.1180-1190, 2017.

HOSHINO, R. T.; ALVES, G. A. C.; BARZAN, R. R.; FREGONEZI, G. A. F.; FARIA, R. T. Fertilizantes agrícolas aplicados via solução nutritiva em Cattleya labiata Lindl. Ornamental Horticulture, Campinas, v. 22, n. 2, p.208-214, 2016.

KAISER, D. R.; BRAGA, F. V. A.; REINERT, D. J.; REICHERT, J. M.; AITA, C. Nitrate leaching in soil management for tobacco cultivation. Aracajú: RBMCSA, 2006. 5 p.

MATOS A. T.; MATOS M. P. Disposal of wastewater in soil and in flooded systems constructed. v. 1. Viçosa: UFV, 2017. $371 \mathrm{p}$.

MARTINS, A. N.; TEIXEIRA, L. A. J.; SUGUINO, E.; HASHIMOTO, J. M. Irrigation and Potassium fertilization via fertirrigation in 'WILLIANS' banana, production and fruit quality. Revista Brasileira de Fruticultura, Cruz das Almas, v. 33, n. 1, p.743-751, 2011.

OLIVEIRA S. L. Irrigation. In: ALVES, É. J. The Banana Culture: technical, socioeconomic and agroindustrial aspects. 2. ed. Brasília, DF: Embrapa - Information Production Service, 1999. p. 317-332.

OLIVEIRA F. C.; MATTIAZZO M. E.; MARCIANO, C. R.; MORAES, S. O., Nitrate leaching in a dystrophic Yellow Latosol treated with sewage sludge and cultivated with sugarcane. Scientia Agricola, Piracicaba, v. 58, n. 1, p.171-180, 2001.

PEREIRA, K. T. O.; OlIVEIRA, F. O.; CAVAlCANTE, A. L. G.; DANTAS, R. P.; OLIVEIRA, M. K. T.; COSTA, J. P. B. M.; Qualidade de mudas de moringa sob diferentes níveis de nutrientes aplicados via fertirrigação. Pesquisa Florestal Brasileira, Colombo, v. 26, n. 88, p.497-504, 2016.

SANTOS, H. G.; JACOMINE, P. K. T.; ANJOS, L. H. C.; OLIVEIRA, V. A.; LUMBRERAS, J. F.; COELHO, M. R.; ALMEIDA, J. A.; CUNHA, T. J. F.; OLIVEIRA, J. B. Sistema brasileiro de classificação de solos. 3.ed. rev. ampl. Brasília, DF: Embrapa, 2013. $353 \mathrm{p}$.

SILVA J. T. A.; BORGES A. L.; DIAS M. S. C.; COSTA, E. L.; PRUDENCE J. M. Nutritional diagnosis of the banana 'Prata-Anã' for the North of Minas. Belo Horizonte: Epamig, 2002. 16 p. (Technical Bulletin, 70).

SILVA, P. F., LIMA, J. G. S., BARROS, A. C., SILVA, E. M.; DUARTE, S. N. Sais fertilizantes e manejo da fertirrigação na produção de tomateiro cultivado em ambiente protegido. Revista Brasileira de Engenharia Agrícola e Ambiental, Campina Grande, v. 17, n. 11, p.1173-1180, 2013. 
TEIXEIRA L. A. J.; QUAGGIO J. A.; MELLIS E. V. Fertilizer efficiency gains in banana under irrigation and fertigation. Revista Brasileira de Fruticultura, Cruz das Almas, v. 33, n. SPE1, p.272-278, 2011.

TEIXEIRA, C. P.; DONAGEMMA, G. K.; FONTANA, A.; TEIXEIRA, W. G. Manual de métodos de análise de solo. 3. ed. rev. e ampl. Brasília, DF: Embrapa, 2017. 573 p. 